\title{
PENERAPAN MEDIA PEMBELAJARAN ADOBE FLASH CS6 DALAM MENINGKATKAN HASIL BELAJAR SISWA KELAS X ATPH PADA MATA PELAJARAN ALAT DAN MESIN PERTANIAN DI SMKN 4 JENEPONTO
}

\author{
Amirah Mustarin, Rahmat Arifyansah, Muh.Rais \\ Program Studi Pendidikan Teknologi Pertanian Fakultas Teknik \\ Universitas Negeri Makassar \\ amirahmustarin@gmail.com
}

\begin{abstract}
ABSTRAK
Penelitian ini adalah penelitian tindakan kelas (classroom action research) yang bertujuan meningkatkan hasil belajar siswa pada mata pelajaran alat dan mesin pertanian kelas $\mathrm{X}$ program keahlian agribisnis tanaman pangan dan holtikultura SMK Negeri 4 Jeneponto dengan penggunaan media pembelajaran Adobe Flash CS6. Subjek penelitian ini adalah siswa kelas X program keahlian agribisnis tanaman pangan dan holtikultura SMK Negeri 4 Jeneponto pada semester ganjil tahun ajaran 2017/2018 yang terdiri dari 34 siswa. Penelitian ini dilaksanakan dalam dua siklus yang terdiri dari empat kegiatan, yaitu: perencanaan, pelaksanaan, pengamatan/observasi dan refleksi. Pengumpulan data hasil belajar dan aktivitas siswa dilakukan dengan menggunakan lembar tes akhir belajar dan lembar observasi pada siklus I dan siklus II. Data yang terkumpul dianalisis secara kuantitatif dan kualitatif. Berdasarkan hasil penelitian dapat disimpulkan bahwa penggunaan media pembelajaran Adobe Flash CS6 dapat meningkatkan hasil belajar siswa kelas X ATPH SMK Negeri 4 Jeneponto. Hasil tes siklus I menunjukkan ketuntasan belajar sebesar $52,94 \%$ dan tes siklus II menunjukkan semua siswa yang berjumlah 34 siswa dinyatakan $100 \%$ tuntas.
\end{abstract}

Kata Kunci: hasil belajar, media pembelajaran Adobe Flash CS6.

\section{ABSTRACT}

This research is a classroom action research, to improve student learning outcomes on the tools and agricultural machinery subject in class $X$ majoring agribusiness food crops and holticulture expertise SMKN 4 Jeneponto with the use of teaching media, Adobe Flash CS6. The subjects of this research were the students of class $X$ agribusiness food crops and holticulture expertise SMK Negeri 4 Jeneponto in the first semester of academic year 2017/2018 that consist of 34 students. This study was conducted in two cycles consisting of four activities, namely: planning, implementation, monitoring/observation and reflection. Data collection and activities of student learning outcomes is done by using a test sheet end of study and observation sheet in the first cycle and the second cycle. The data were analyzed quantitatively and qualitatively. Based on the results of this study concluded that the use of Adobe Flash CS6 can improve the learning outcomes of class $X$ ATPH SMKN 4 Jeneponto. The first cycle test showed learning completeness $52.94 \%$ and the second cycle test showed that all students, 34 students, were declared $100 \%$ complete.

Keywords: Learning Outcomes, Teaching Media Adobe Flash CS6 


\section{PENDAHULUAN}

Media pembelajaran memiliki peranan penting dalam menunjang kualitas proses belajar mengajar. Media juga dapat membuat pembelajaran lebih menarik dan menyenangkan. Namun dalam media pembelajaran sangat tergantung dari kemampuan guru dalam penyajian media pada proses pembelajaran. Media pembelajaran yang dikemas dengan baik akan memberikan kontribusi dalam peningkatan hasil belajar siswa. Begitupun sebaliknya jika disajikan dengan cara yang tidak tepat menyebabkan kemampuan siswa sulit dikembangkan.

Kunci keberhasilan dalam penyampaian media yaitu diperolehnya hasil belajar yang meningkat dari sebelumnya, maka seorang guru dituntut untuk membuat media pembelajaran dalam menyampaikan materinya yang sesuai dengan kondisi siswa sehingga, siswa merasakan suasana yang menarik dalam proses belajarnya. Agar pembelajaran efektif dan fungsional maka fungsi media pembelajaran sangat penting untuk dimanfaatkan (Febrianto, 2017). Namun kenyataanya hampir disetiap sekolah menengah belum diterapkan media pembelajaran, sehingga materi yang harus disampaikan dengan contoh yang real belum tersampaikan dengan baik hanya sekedar penjelasan berbasis ceramah.

SMK Negeri 4 Jeneponto merupakan sekolah yang dalam proses belajar mengajarnya masih menggunakan media konvensional sehingga siswa merasa kurang mengerti tentang Alat dan Mesin Pertanian.

Media pembelajaran diharapkan menjadi solusi dalam mengembangkan hasil belajar siswa karena dari hasil belajar yang didapatkan melalui wawancara terhadap beberapa siswa, mereka menginginkan susasan pembelajaran yang menarik dan bervariasi. Sebagian besar siswa hanya menghafal pembelajaran yang diberikan tanpa memahami sehingga pada saat evaluasi siswa tidak mampu menjawab pertanyaan yang diberikan oleh guru dengan baik.

Keadaan yang seperti demikian menyebabkan hasil belajar siswa pada mata pelajaran penerapan konsep mutu hasil pertanian memperoleh nilai dibawah standar kriteria ketuntasan minimal (KKM) yaitu 70 . Hanya sekitar 28 siswa yang lulus dengan nilai rata-rata $71-100$ dengan presentasi $73 \%$ sementara indikator keberhasilan yang ingin dicapai adalah $80 \%$ atau 31 orang jumlah siswa yang harus lulus pada mata pelajaran tersebut.

Salah satu strategi yang dapat meningkatkan keaktifan dan hasil belajar siswa dengan mata pelajaran Alat dan Mesin Pertanian pada kelas X ATPH SMK Negeri 4 Jeneponto yaitu menggunakan media. Media secara khusus menurut Gerlach \& Ely (Arsyad, 2013), bahwa media jika dipahami secara garis besar adalah manusia, materi, atau kejadian yang membangun kondisi, yang menyebabkan siswa mampu memperoleh pengetahuan, keterampilan, atau sikap. Dalam hal ini yang dimaksud dari pendapat diatas yaitu guru, buku, teks dan lingkungan sekolah merupakan media. Media yang tepatnya peneliti gunakan adalah media Adobe Flash CS6. Adobe Flash CS6 merupakan software yang mampu menghasilkan presentasi, game, film, CD interaktif, maupun CD pembelajaran, serta untuk membuat situs web yang interaktif, menarik, dan dinamis. Adobe Flash CS6 merupakan versi Adobe Flash yang telah diperbarui dari versi sebelumnya yaitu Adobe Flash CS3, Adobe Flash CS4, dan Adobe 
Flash CS5 (Madcoms, 2013). Adobe Flash CS6 mampu melengkapi situs web dengan beberapa macam animasi, suara, animasi interaktif dan lain-lain (Ichwan,2015).

Media Adobe Flash CS6 ini sangat baik digunakan pada pelajaran Alat dan Mesin Pertanian karena media Adobe Flash CS6 ini mempunyai unsur gambar, efek suara, animasi serta tampilan menarik yang mapu menggugah perasaan dan pemikiran siswa. Software Adobe Flash CS 6 Profesional menghasilkan produk dalam bentuk exe (Saselah, dkk, 2017). Sebagaimana hasil penelitian sebelumnya Rina Izatul Lailiya (2015) yang mengemukakan bahwa penerapan media Adobe Flash CS6 ini sangat layak sebagai media pembelajaran.

Berdasarkan uraian yang dikemukakan, maka peneliti melakukan penelititan tindakan kelas di SMK Negeri 4 Jeneponto. Dengan judul penelitia Penerapan Media Pembelajaran Adobe Flash CS6 dalam Meningkatkan Hasil Belajar Siswa Kelas X ATPH Pada Mata Pelajaran Alat dan Mesin Pertanian di SMK Negeri 4 Jeneponto.

Masalah yang akan dikaji dalam penelitian ini adalah:"Apakah penerapan media pembelajaran Adobe Flash CS6 akan meningkatkan hasil belajar siswa kelas $X$ ATPH pada mata pelajaran Alat dan Mesin Pertanian di SMK Negeri 4 Jeneponto?

Tujuan penelitian ini adalah Untuk mengetahui penerapan media pembelajaran Adobe Flash CS6 bagi siswa kelas X ATPH pada mata pelajaran Alat dan Mesin Pertanian di SMK Negeri 4 Jeneponto.

Manfaat yang diharapakan dari penelitian tindakan kelas ini dapat dijadikan bahan informasi sebagi masukan bagi lembaga-lembaga pendidikan yang berguna untuk meningkatkan mutu pendidikan dan menambah wawasan di bidang pendidikan dan pengajaran terutama menyangkut media pembelajaran Adobe Flash CS6. Bagi guru adalah untuk meningkatkan mutu proses belajar mengajar (mengembangkan diri) dengan menggunakan model pembelajaran yang bervariasi untuk meningkatkan mutu kelulusan dan kompotensi siswa. Bagi Peneliti untuk menambah pengetahuan dan pengalaman serta sebagai bahan acuan bagi penelitian selanjutnya.

\section{METODE PENELITIAN}

Penelitian ini adalah Penelitian Tindakan Kelas (Classroom Action Research) yang dilaksanakan dalam siklus berulang, dimana setiap siklus terdiri atas rangkaian empat kegiatan yaitu, perencanaan tindakan, pelaksanaan tindakan, observasi (evaluasi), dan refleksi.

Penelitian ini dilaksankan di SMK Negeri 4 Jeneponto.Waktu penelitian dilaksanakan awal semester ganjil tahun ajaran 2017/2018.

Adapun yang menjadi subjek penelitian ini adalah siswa Kelas X ATPH di SMK Negeri 4 Jeneponto yang berjumlah sebanyak 34 orang.

Teknik pengumpulan data pada penelitian ini melalui metode observasi dan metode tes hasil belajar.

\section{Prosedur Penelitian}

Prosedur Penelitian Tindakan Kelas (PTK) ini dilakukan selama dua siklus. Setiap siklus dilaksanakan dengan 2 kali pertemuan sesuai dengan perubahan yang ingin dicapai antara siklus I dengan siklus || yang merupakan komponen yang saling berkaitan.

Penelitian tindakan kelas ini dikatakan berhasil apabila hasil belajar siswa rata-rata mencapai nilai kriteria ketuntasan 
minimal (KKM) 75 sekurang-kurangnya 85\% dari jumlah siswa pada kelas X ATPH di SMK Negeri 4 Jeneponto.

\section{HASIL DAN PEMBAHASAN}

Data hasil belajar siswa dari pelaksanaan siklus I dan siklus || pada pembelajaran Alat dan Mesin Pertanian yang diperoleh dari hasil analisis statistik deskriptif yang dimaksudkan untuk mendeskripsikan

Tabel 1

Hasil belajar peserta siswa kelas X ATPH SMK Negeri 4 Jeneponto

\begin{tabular}{|l|l||c|c|c|}
\hline \multirow{2}{*}{ No } & \multirow{2}{*}{ Statistik } & \multicolumn{3}{c|}{ Nilai statistic } \\
\cline { 3 - 5 } & & Sebelum Tindakan & Siklus I & Siklus II \\
\hline 1 & Jumlah Siswa & 34 & 34 & 34 \\
\hline 2 & Nilai Ideal & 100 & 100 & 100 \\
\hline 3 & Nilai Tertinggi & 85 & 90 & 95 \\
\hline 4 & Nilai Terendah & 15 & 45 & 75 \\
\hline & Rata-rata & 55,88 & 73,24 & 86,03 \\
\hline
\end{tabular}

Ketuntasan belajar pada mata pelajaran Alat dan Mesin Pertanian dapat dilihat berdasarkan kemampuan peserta didik memahami konsep melalui media pembelajaran Adobe Flash CS6. Dengan melihat kategori tuntas dan tidak tuntas dari

Tabel 2

Deskripsi ketuntasan belajar peserta didik kelas X ATPH SMK Negeri 4 Jeneponto

\begin{tabular}{|c|c|c|c|c|c|c|c|}
\hline \multirow{2}{*}{ Kategori } & \multirow{2}{*}{ Nilai } & \multicolumn{2}{|c|}{ Sebelum Tindakan } & \multicolumn{2}{|c|}{ Siklus I } & \multicolumn{2}{|c|}{ Siklus II } \\
\hline & & $\begin{array}{l}\text { Fre- } \\
\text { Kuensi }\end{array}$ & $\begin{array}{c}\text { Persen } \\
(\%)\end{array}$ & $\begin{array}{l}\text { Fre- } \\
\text { kuensi }\end{array}$ & $\begin{array}{c}\text { Persen } \\
(\%)\end{array}$ & $\begin{array}{c}\text { Fre- } \\
\text { kuensi }\end{array}$ & $\begin{array}{c}\text { Persen } \\
(\%)\end{array}$ \\
\hline Tidak Tuntas & $0-74$ & 30 & 88,24 & 16 & 47,06 & 0 & 0 \\
\hline Tuntas & $75-100$ & 4 & 11,76 & 18 & 52,94 & 34 & 34 \\
\hline \multicolumn{2}{|c|}{ Jumlah } & 34 & 100 & 34 & 100 & 34 & 100 \\
\hline
\end{tabular}


Berdasarkan hasil analisis kualitatif dan kuantitatif, terlihat pada pelaksanaan pembelajaran menggunakan media pembelajaran Adobe Flash CS6 memberikan perubahan hasil belajar pada siswa. Hasil penelitian yang telah dilakukan dengan menggunakan media Adobe Flash CS6 dalam pembelajaran Alat dan Mesin Pertanian diperoleh adanya peningkatan hasil belajar pada siswa kelas X ATPH SMK Negeri 4 Jeneponto dari siklus I ke siklus II.

Penggunaan media Adobe Flash CS6 dalam pembelajaran yang diterapkan seorang guru merupakan salah satu faktor yang menentukan ketercapaian hasil belajar peserta didik, karena media yang sesuai dengan materi yang akan diajarkan dapat mendorong semangat siswa dalam mengikuti proses pembelajaran sehingga mempermudah siswa dalam memahami materi yang diajarkan oleh guru yang tentunya akan dapat meningkatkan hasil belajar.

\section{Sebelum Tindakan}

Dari tabel 2 dapat di jelaskan bahwa rendahnya presentase ketuntasan hasil belajar siswa kelas $X$ ATPH SMKN 4 Jeneponto, dimana ketuntasan belajar sebesar $88,24 \%$ atau 30 orang siswa belum tuntas belajar. Hasil tersebut menunjukan bahwa tes awal (Pre-Test) secara klasikal belum tuntas belajar, karena siswa yang memperoleh nilai $\geq 75$ sebesar $11,76 \%$ atau 4 orang siswa dinyatakan tuntas belajar. Oleh sebab itu diperlukan perencanaan sebelum menerapkan media pembelajaran Adobe Flash CS6 agar efektif dan fungsional pada mata pelajaran Alat dan Mesin Pertanian. Kegiatan perencanaan tindakan dilaksanakan sebelum pembelajaran dan penggunaan media Adobe Flash CS6. Perencanaan ini meliputi: a) Guru bersama peneliti mendiskusikan rancangan tindakan yang akan dilakukan kemudian disepakati bahwa pelaksanaan tindakan disetiap siklus sebanyak 2 kali pertemuan dengan alokasi waktu 135 menit per stau kali pertemuan

b) Mengkaji kurikulum SMK Negeri 4 Jeneponto semester ganjil mata pelajaran Alat dan Mesin Pertanian yang berkaitan dengan tema penelitian yang dilakukan.

c) Melakukan dialog awal yang digunakan untuk permasalahn awal dan dijadikan pijakan untuk melakukan rencana perbaikan pembelajaran

d) Merancang program pembelajaran berupa Rencana Pelaksanaan Pembelajaran (RPP) sesuai dengan silabus untuk pelasanaan tindakan dengan menggunakan media Adobe Flash CS6

e) Membuat instrumen penelitian soal tes awal (Pre-test) untuk siklus I dan II untuk melakuka evaluasi disetiap akhir siklus dan selanjutnya dilakukan validasi instrumen penelitian kepada validator

f) Soal tes yang dirancang adalah soal pilihan ganda berjumlah 20 butir soal yang akan diujika kepada siswa pada pertemuan ke-3 sekaligus sebagi tes akhir siklus

g) Instrumen non tes yan berupa lembar observasi yang telah disiapkan dan dilakukan setiap petemuan berlangsung

\section{Siklus I}

Pada Siklus I berdasarkan tabel 2 masih ada 16 siswa dari 34 siswa yang menjadi subjek penelitian yang hasil belajarnya menunjukkan berada pada 
kategori tidak tuntas, jumlah tersebut menunjukan masih sangat rendahnya ketuntasan pada siklus I yakni hanya sekitar $47,06 \%$ data tersebut masih jauh dari indikator keberhasilan yang diinginkan yaitu $85 \%$, oleh sebab itu diperlukan perbaikanperbaikan untuk melanjutkan kesiklus berikutnya agar hasil belajar siswa dapat meningkat dan memenuhi kriteria ketuntasan minimal dan indikator keberhasilan yang ingin dicapai. Faktorfaktor yang menyebabkan hasil belajar siswa berada pada kategori tidak tuntas yaitu :

a. Guru masih sangat kurang baik dalam memotivasi siswa dan dalam menyampaikan tujuan pembelajaran.

b. Guru masih kurang menumbuhkan partisipasi aktif dari siswa.

c. Guru tidak mengaitkan pelajaran yang akan diajarakan dengan materi sebelumnya.

d. Kurang siswa yang mencatat materi pelajaran yang diajarakan oleh guru

e. Masih banyak siswa yang terlihat kurang memperhatikan materi yang disampaikan oleh guru.

f. Media Adobe Flash CS6 yang dibuat oleh guru masih belum sesuai dengan materi pelajaran sehingga efek kemenarikan media Adobe Flash CS6 belum terpenuhi.

g. Penggunaan baground dan Tempelate pada media Adobe Flash CS6 belum sesuai dengan materi yang akan diajarkan oleh guru sehingga siswa kurang memperhatikan dan sulit menyerap materi pelajaran dan mengurangi efek kemenarikan dari media Adobe Flash CS6 tersebut.
Adapun langkah-langkah sebagai hasil refleksi Siklus I dalam pelaksanaan Siklus II meliputi

a) Guru harus lebih terampil dalam memotivasi siswa dan lebih jelas dalam menyampaikan tujuan pembelajaran.

b) Guru perlu mendistribusikan waktu secara baik dengan menambah informasi yang dirasa perlu untuk diberikan.

c) Guru harus lebih terampil dalam menumbuhkan partisipasi aktif siswa dalam proses pembelajaran.

d) Guru harus mampu menghubungkan pelajaran yang akan diajarakan dengan materi sebelumnya.

e) Pemberian modul agar siswa lebih fokus memperhatikan guru menjelaskan materi pelajaran.

f) Pemberian tugas rumah kepada peserta didik diakhir pembelajaran.

g) Menyesuikan penggunaan fitur-fitur pada media Adobe Flash CS6 dengan materi pelajaran sehingga meningkatkan efek kemenarikan media Adobe Flash CS6 dan dapat memusatkan perhatian siswa selam proses pembelajaran.

\section{Siklus II}

Siklus II dilakukan setelah merefleksikan pelaksanaan Siklus I, kemudian diperoleh gambaran tindakan yang dilakukan pada Siklus II sebagai perbaikan dari pelaksanaan Siklus I, sehingga hasil belajar yang diperoleh pada penelitian ini sesuai dengan yang diharapkan.Pada siklus II peningkatan hasil belajar siswa telah mencapai standar KKM untuk mata pelajaran Alat dan Mesin Pertanian yaitu 75 serta mencapai ketuntasan klasikal yaitu $85 \%$ dari jumlah 
siswa yang ada. Hal ini dapat dilihat dari hasil belajar peserta didik kelas X ATPH yang menunjukkan nilai ketuntasan yang diperoleh dari hasil tes awal yaitu jumlah peserta didik yang tidak tuntas sebanyak 30 siswa atau $88,24 \%$, yang menggambarkan bahwa keseluruhan peserta didik pada kategori tidak tuntas, kemudian pada hasil belajar siklus I dengan jumlah siswa yang tidak tuntas sebanyak 16 orang dengan persentase $47,06 \%$ dan jumlah peserta didik yang tuntas sebanyak 18 orang dengan persentase $52,94 \%$. Selanjutnya dari hasil tes siklus II menunjukkan semua siswa yang berjumlah 34 siswa dinyatakan $100 \%$ tuntas.

Berdasarkan tabel 2 diperoleh presentase ketuntasan belajar siswa pada siklus II sebesar $100 \%$ atau 34 siswa sudah tuntas belajar. Hasil tersebut menunjukan bahwa tes akhir siklus II secara klasikal sudah tuntas belajar, karena diperoleh presentase ketuntasan belajar sebesar $100 \%$ menunjukan telah memenuhi indikator keberhasilan yang dikehendaki yaitu $85 \%$. Selain adanya peningkatan hasil belajar siswa, juga adanya peningkatan terhadap aktivitas peserta didik dalam proses pembelajaran.

Penggunaan media pembelajaran Adobe Flash CS6 memberikan manfaat dan pengaruh yang sangat nyata dalam meningkatkan aktivitas siswa terutama pada hasil belajarnya. Hasil penelitian ini didukung dengan hasil penelitian Ardimas (2015) yang menyimpulkan bahwa pemanfaatan media presentasi Adobe Flash CS6 dapat meningkatkan hasil belajar peserta didik pada mata pelajaran Listrik DC di MAN Lab UIN Yogyakarta.

Maka secara umum dengan menggunakan media pembelajaran Adobe Flash CS6 dapat meningkatkan hasil belajar siswa kelas $X$ ATPH SMK Negeri 4 Jeneponto pada mata pelajaran Alat dan Mesin Pertanian.

\section{KESIMPULAN}

Berdasarkan uraian data hasil belajar peserta didik pada mata pelajaran Alat dan Mesin Pertanian pada pembahasan hasil penelitian, maka dapat disimpulkan bahwa penerapan media pembelajaran Adobe Flash CS6 dapat meningkatkan hasil belajar siswa kelas X ATPH SMK Negeri 4 Jeneponto dari siklus I ke siklus || serta terjadi peningkatan positif aktivitas siswa kelas X ATPH SMK Negeri 4 Jeneponto.

\section{SARAN}

Dari hasil penelitian yang diperoleh agar proses belajar mengajar pada mata pelajaran Alat dan Mesin Pertanian lebih memberikan hasil yang optimal bagi siswa maka disampaikan saran sebagai berikut:

1. Dalam penerapan media Adobe Flash CS6 pada proses pembelajaran diperlukan persiapan yang cukup matang dan keterampilan khusus sehingga guru harus mampu memilih ide yang cukup menarik untuk dituangkan ke dalam Adobe Flash cS6.

2. Diharapkan kepada guru-guru terkhusus guru SMKN 4 Jeneponto dapat mempertimbangkan media yang digunakan dalam proses pembelajaran sebagai upaya meningkatkan hasil belajar siswa yang lebih baik.

\section{DAFTAR PUSTAKA}

Arsyad, Azhar. 2013. Media Pembelajaran. Jakarta: PT Raja Grafindo Jakarta Persada. 
Febrianto. 2017. Analisis Penerapan Media Pembelajaran Prezi terhadap Hasil Belajar Siswa Kelas X TPHP pada Mata Pelajaran Pengendalian Mutu Dalam Proses Pengolahan di Smk Negeri 3 Takalar. Jurnal Pendidikan Teknologi Pertanian, Vol. 3, No. 43:48

Ichwan, K. 2015. Membuat media Pembelajaran dengan adobe Flash CS6. Yogyakarta: CV. Andi Offset.

Lailiya, Rina Izlatul. 2015. Pengembangan Media Pembelajaran berbasis Adobe Flash CS6 pada Materi Jurnal Penyesuaian Perusahaan Dagang Kelas X-AK SMK Muhammadiyah Taman. Jurnal Pendidikan Akuntansi. Vol.3, No.1:10.

Madcoms. 2013. Mahir dalam 7 Hari Adobe Flash CS6. Yogyakarta: Andi Publisher.

Saselah, dkk. 2017. Pengembangan Multimedia Interaktif berbasis Adobe Flash CS6 Profesional pada Pembelajaran Kesetimbangan Kimia. Jurnal Kimia dan Pendidikan $\begin{array}{lll}\text { Kimia.Vol 2, No. 2:17. } & \text { No. }\end{array}$ 